\title{
Upper extremity injuries due to threshing machine
}

\author{
Harman dövme makinesine bağlı üst ekstremite yaralanmaları
}

\author{
Dağhan IŞIK, ${ }^{1}$ M. Fethi CEYLAN, ${ }^{2}$ Hakan TEKİN, ${ }^{1}$ Sevdegül KARADAŞ, ${ }^{3}$ \\ Savaş GÜNER, ${ }^{2}$ Yasin CANBAZ ${ }^{1}$
}

\section{BACKGROUND}

The aim of this study was to report the patients who were admitted to our hospital with upper extremity injuries due to threshing machine, to determine the most appropriate classification, to estimate the treatment modalities, and to discuss the prevention methods.

\section{METHODS}

Twenty-five patients who had suffered injuries sustained by a threshing machine were retrospectively investigated. The patients were analyzed with respect to age, gender, admission month, hospitalization period, the type of injured tissue, and the treatment modality.

\section{RESULTS}

Twenty-four of the patients were male and one was female, and the mean age of the patients was 19.4 (2-51) years; $60 \%$ of the patients were under the age of 15 . The patients were admitted most commonly in the month of August.

\section{CONCLUSION}

We believe that shielding the rotating components of farming machinery that cause injuries, informing and educating farming families (by physicians), forbidding the entrance of children to areas with agricultural machines, providing information to children in schools (in those regions with developing agriculture) about agricultural accidents and their prevention methods, and adjusting the working hours of farming personnel, especially in the hottest months of the year, may be beneficial in preventing accidents due to farming machinery.

Key Words: Agricultural workers; agricultural worker's disease; amputation; hand injuries; classification.

\begin{abstract}
AMAÇ
$\mathrm{Bu}$ çalışmanın amacı, hastanemize başvuran harman dövme makinesine bağlı üst ekstremite yaralanması bulunan hastaları sunmak, en uygun sinıflandırmayı belirlemek, tedavi seçeneklerini değerlendirmek ve korunma yollarını tartışmaktır.
\end{abstract}

\section{GEREÇ VE YÖNTEM}

Harman dövme makinesine bağlı yaralanması olan 25 hasta geriye dönük olarak incelendi. Hastaların yaşları, cinsiyetleri, başvuru ayları, hastanede kalma süreleri, yaralanan dokuların çeşidi ve uygulanan tedaviler açısından analiz edildi.

\section{BULGULAR}

Hastaların 24'ü erkek 1'i kadın ve yaş ortalamaları 19,4 (dağılım, 2-51 yaş) idi. Hastaların \%60’1 15 yaşın altındayd. Hastalar en çok Ağustos ayında başvuru yaptılar.

\section{SONUÇ}

Tarım makinelerinin yaralanmaya sebep olan dönen parçalarının korunaklarla saklanmasının, tarım ile uğraşan ailelerin sağlık çalışanları tarafından bilgilendirilmelerinin, çocukların tarım makinelerinin olduğu bölgelere girmelerinin yasaklanmasının, tarım sektörünün geliştiği bölgelerdeki okullarda çocuklara tarım kazaları ve önleme yolları hakkında bilgi verilmesinin, yılın en sıcak olduğu aylarda tarım çalışanlarının mesai saatlerinde ayarlamalar yapılmasının tarım makinelerine bağlı kazaların önlenmesinde faydalı olacağı kanaatindeyiz.

Anahtar Sözcükler: Tarım işçileri; tarım işçileri hastalıkları; amputasyon; el yaralanmaları; sinıflandırma. ${ }^{3}$ Acil Tip Anabilim Dalı, Van. 
It is seen that there has been an increase in the type and number of farming machines to increase the productivity in the farming sector. In England, the rate of accidents in the farming sector is more than that in the many other industrial fields. ${ }^{[1]}$ In the United States, in 1992, \$4.57 billion was spent for farming accidents. ${ }^{[2]}$ One of the farming machines used to increase productivity, especially in cereal agriculture, is the threshing machine. The thresher is a device pulled and powered by a tractor that separates the hay and chaff from wheat or grain (Fig. 1). When the time for collecting the product emerges, thresher and other agricultural machine accidents that commonly result in injuries to the upper extremities begin to be seen.

In this report, we discuss the classification of 25 patients with threshing machine injury who were retrospectively analyzed and their treatments, together with the related literature.

\section{MATERIALS AND METHODS}

Twenty-five patients ranging in age from 2 to 51 (mean: 19.4) years, whose upper extremities were injured by a threshing machine between January 2007 - December 2009, were retrospectively analyzed with regard to their injured regions and treatment modalities. The patients were divided into six groups for classification according to their injury type as follows: 1st degree: Patients with only soft tissue injury (5 patients); 2nd degree: Patients with tendon damage with/ without first-degree injury (2 patients); 3rd degree: Patients with bone fracture with/without second-degree injury (3 patients); 4th degree: Patients with vascular/ neural damage with/without third-degree injury (3 patients); 5th degree: Patients with amputation in the finger region (10 patients); and 6th degree: Patients with amputation of the hand or more proximal regions (2 patients) (Table 1).

\section{RESULTS}

The number of patients in each injury group is given in Table 1. One of the patients was female, while the remaining 24 were male. Fifteen of the patients were children (under 15 years of age) and 10 were adults (Table 2). The mean hospitalization time of the patients was 4.0 (1-26 days) days. The most commonly

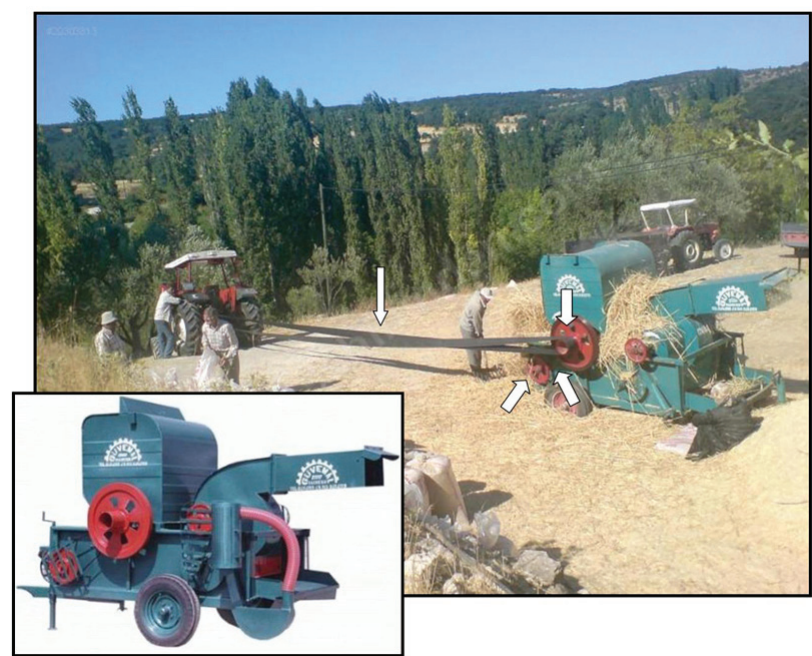

Fig. 1. The threshing machine. The arrows indicate the parts of the machinery responsible for injuries.

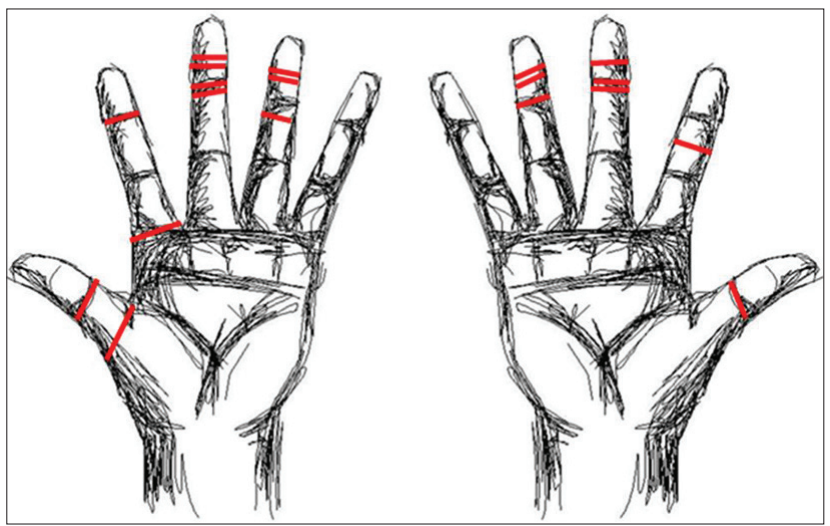

Fig. 2. The scheme showing amputation levels (total and subtotal) in the hands of the patients with 5 th degree injury.

(Color figures can be viewed in the online issue, which is available at www.tjtes.org)

observed injury was the 5th degree injury and the most commonly affected fingers in this group were the third and fourth fingers (Fig. 2). While 14 of the patients had left upper extremity injury (Fig. 3), 10 had right upper extremity injury (Fig. 4), and 1 had bilateral upper extremity injuries. The injuries were most commonly observed in August (Table 3). Fifteen of the accidents due to threshing machine occurred in 2009, while 7 occurred in 2008, and 3 in 2007 (Table 4).

Table 1. Classification and treatment algorithm for threshing machine injuries

\begin{tabular}{lll}
\hline Injury/Number of pts & Injured tissue & Treatment modalities \\
\hline 1st degree / 5 patients & Patients with only soft tissue injury & PS, covering with skin grafting or flap \\
2nd degree / 2 patients & Patients with tendon injury \pm 1st degree injury & TR \pm repair of 1st degree injury \\
3rd degree / 3 patients & Patients with bone fracture \pm 2nd degree injury & Bone fixation (ORIF, KW) \pm repair of 2nd degree injury \\
4th degree / 3 patients & Patients with vascular / neural injury \pm 3rd degree injury & VR / NR \pm repair of 3rd degree injury \\
5th degree /10 patients & Patients with amputations on fingers & SR (PR, with LF or grafting), revascularization, re-implantation \\
6th degree / 2 patients & Patients with amputations of the hand or more proximal part & Vessel ligation and SR (PR, with LF or grafting), re-implantation \\
\hline
\end{tabular}

ORIF: Open reduction internal fixation; KW: K-wire; VR: Vein repair; NR: Nerve repair; AR: Arterial repair; TR: Tendon repair; PR: Primary repair; SR: Stump repair; PS: Primary saturation; LF: Local flap. 

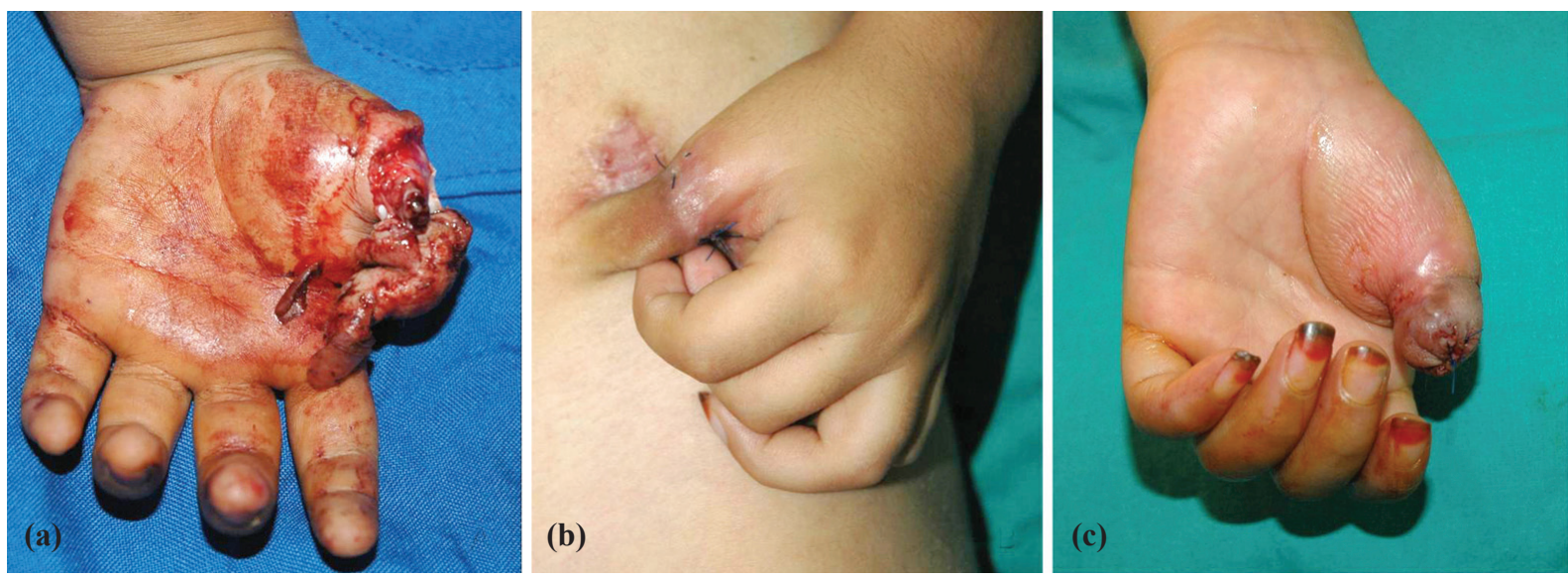

Fig. 3. Appearance of Case 22 preoperatively (a), after the first operation (paraumbilical flap application) (b), and at the 3rd postoperative week (c).

(Color figures can be viewed in the online issue, which is available at www.tjtes.org)

\section{DISCUSSION}

Technologies used to increase productivity in agriculture require the intense use of farming machines. Increase in the numbers and diversities of agricultural enterprises bring about work accidents. In the literature, injuries due to farming machines including corn-picker, ${ }^{[3-6]}$ wheat thresher, ${ }^{[7]}$ grain auger, ${ }^{[8-10]}$ or hay baler ${ }^{[11]}$ have been reported. These accidents in agricultural enterprises result in income loss, production loss, material defects in devices, and high ex-

Table 2. Demographic features, injury type and applied treatment modalities in patients with hand injury due to threshing machine

\begin{tabular}{|c|c|c|c|c|}
\hline No & Age/Sex & Injury type & Applied treatment & Degre \\
\hline 1 & 28/M & $\begin{array}{l}\text { Subtotal amputation from the DIP joint of 3rd finger and IP joint of } 1 \text { st finger of the left hand, } \\
\text { severed digital nerve and artery in 3rd finger (no circulation in the 3rd finger) }\end{array}$ & $\begin{array}{l}\text { KW and TR (1st finger), } \\
\text { AR, NR, PS (3rd finger) }\end{array}$ & 4 \\
\hline 2 & $13 / \mathrm{M}$ & $\begin{array}{l}\text { Abrasion of the left hand's 2nd-3rd-4th-5th fingers with deep cut in MCP joint of the } 2 \text { nd and } \\
5 \text { th fingers, severed nerve and artery, no circulation in the 5th finger }\end{array}$ & Revascularization, NR, PS & 4 \\
\hline 3 & $18 / \mathrm{M}$ & Subtotal amputation at the DIP joint of the right hand 3rd and 4th fingers, severed tendon & $\begin{array}{l}\mathrm{V}-\mathrm{Y} \text { advancement flap and } \\
\text { repair with pullout }\end{array}$ & 2 \\
\hline 4 & $44 / \mathrm{M}$ & Total amputation from the distal phalanx of the 2 nd finger of the left hand & $\begin{array}{l}\text { Stump repair with V-Y } \\
\text { advancement flap }\end{array}$ & 5 \\
\hline 5 & $5 / \mathrm{M}$ & Near total amputation from the distal part of the 4 th finger of the right hand & Use of amputate as graft & 5 \\
\hline 6 & $7 / \mathrm{M}$ & Subtotal amputation from the proximal part of the nail bed of the $3 \mathrm{rd}$ and 4 th fingers on the left hand & Repair with primary saturation & 1 \\
\hline 7 & $31 / \mathrm{M}$ & Abrasion on the posterior of the right arm & $\begin{array}{l}\text { Left for secondary repair with } \\
\text { dressing }\end{array}$ & 1 \\
\hline 8 & 4/M & Separation and cut in the epiphysis of the IP joint of the left hand's first finger, severed digital nerve & Suturation and placing in splint, NR & 4 \\
\hline 9 & $12 / \mathrm{M}$ & Total amputation in a crushing manner, from the DIP joint on the 3rd finger of the left hand & SR with V-Y advancement flap & 5 \\
\hline 10 & $6 / \mathrm{M}$ & $\begin{array}{l}\text { Partially severed extensor tendon on the } 3 \text { rd and totally severed tendon on the } 4 \text { th and } 5 \text { th fingers of } \\
\text { the right hand, fracture of the carpal bones }\end{array}$ & TR, KW & 3 \\
\hline 11 & $26 / \mathrm{F}$ & Total amputation from IP joint of right hand thumb; Degloving in proximal phalanx & Reparation with para-umbilical flap & 5 \\
\hline 12 & $15 / \mathrm{M}$ & Total amputation from the nail bed of the $3 \mathrm{rd}$ and 4 th fingers of the right hand & SR with V-Y advancement flap & 5 \\
\hline 13 & $51 / \mathrm{M}$ & Subtotal amputation at zone 1 of the 3 rd and 4 th fingers & PS, KW (4th finger), LF (3rd finger) & 3 \\
\hline 14 & $14 / \mathrm{M}$ & Distal end defect on the DIP joint of the 3 rd finger and volar part of the 4 th finger of the right hand & FTSG (3rd finger), PS (4th finger) & 1 \\
\hline 15 & $18 / \mathrm{M}$ & Total amputation from the proximal of the distal phalanx of the 4 th finger on the left hand & SR & 5 \\
\hline 16 & $2 / \mathrm{M}$ & Cut on the volar part of the distal phalanx of the 5 th finger of the left hand & PS & 1 \\
\hline 17 & $4 / \mathrm{M}$ & $\begin{array}{l}\text { Amputation from the metacarpal bone of the } 2 \text { nd finger of the left hand, comminuted fracture of } \\
\text { the metacarpal of the } 3 \text { rd finger, fracture of the distal phalanx of the } 4 \text { th finger }\end{array}$ & AR, NR, TR, KW & 5 \\
\hline 18 & $36 / \mathrm{M}$ & Amputation from the mid part of the middle phalanx of the 2 nd finger of the right hand & SR & 5 \\
\hline 19 & $36 / \mathrm{M}$ & Tissue defect on the pulp of the 5 th finger of the left hand & Left for secondary repair & 1 \\
\hline 20 & $4 / \mathrm{M}$ & $\begin{array}{l}\text { Cut on the distal phalanx of the 2nd finger of the right hand, subtotal amputation from } \\
\text { the distal phalanx of the 3rd finger, FDP cut on the 2nd finger }\end{array}$ & PS (2nd finger), TR and PS (3rd finger) & 2 \\
\hline 21 & $3 / \mathrm{M}$ & Total amputation of the left hand 3rd and 4th fingers from the beginning of the nail bed & SR & 5 \\
\hline 22 & $4 / \mathrm{M}$ & $\begin{array}{l}\text { De-gloving amputation of the left hand first finger from the MCP joint, fracture of } \\
\text { the proximal phalanx }\end{array}$ & $\begin{array}{l}\text { Phalanx stabilization, } \\
\text { Para-umbilical flap }\end{array}$ & 5 \\
\hline 23 & 46/M & $\begin{array}{l}\text { Metacarpal fracture of the left hand 1st and 2nd fingers, radius open fracture, } \\
\text { tissue defect on dorsal forearm }\end{array}$ & $\begin{array}{l}\text { Dorsal interosseous flap for } \\
\text { tissue defect }\end{array}$ & 3 \\
\hline 24 & $45 / \mathrm{M}$ & $\begin{array}{l}\text { Bilaterally amputation over the elbow. Left arm was amputated from the level of } \\
\text { deltoid insertion on proximal } 1 / 3 \text { and right arm was amputated from distal } 1 / 3 \text { level }\end{array}$ & SR & 6 \\
\hline 25 & $14 / \mathrm{M}$ & Amputation from right elbow & SR & 6 \\
\hline
\end{tabular}

KW: K-wire; NR: Nerve repair; AR: Arterial repair; TR: Tendon repair; PR: Primary repair; SR: Stump repair; PS: Primary saturation; LF: Local flap; FDP: Flexor digitorum profundus; FTSG: Full-thickness skin graft. 

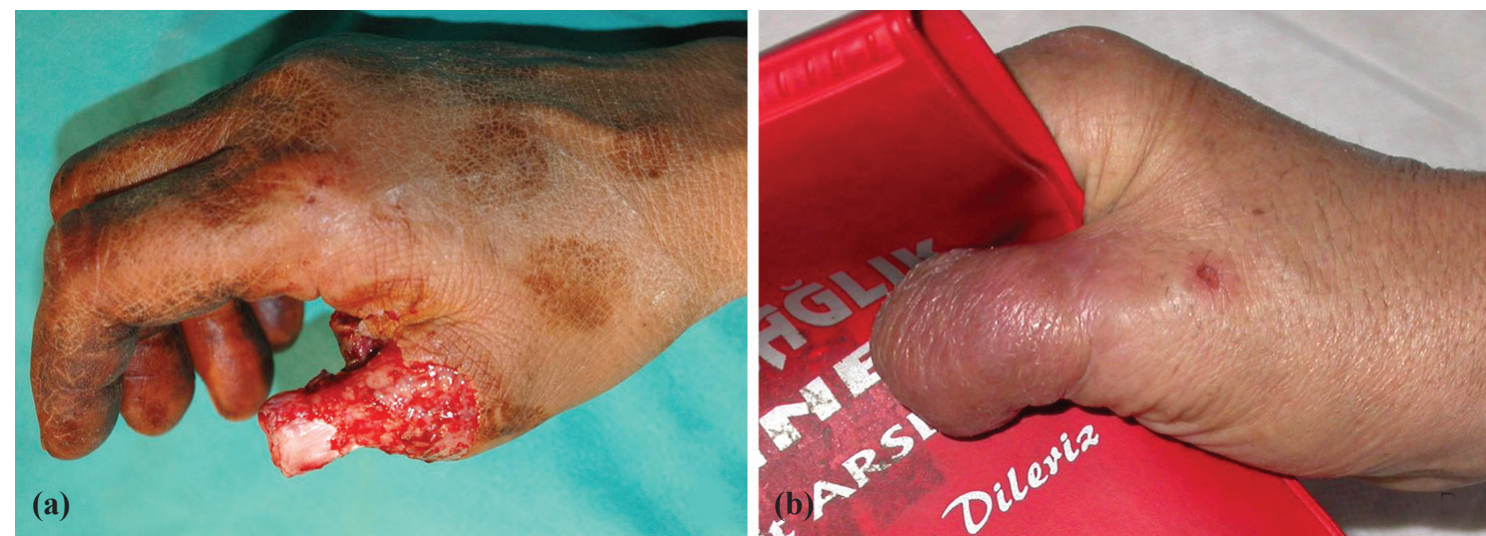

Fig. 4. Preoperative (a) and postoperative (b) appearance of Case 11.

(Color figures can be viewed in the online issue, which is available at www.tjtes.org)

penditures due to physical disabilities. ${ }^{[2,12]}$

In 1954, Maxim et al. ${ }^{[6]}$ used the term "corn-picker hand" for the hand injures due to corn-picker. In the 1950's, when debridement and stump closing were generally performed for corn-picker injuries, the term "corn-picker hand" seemed to be appropriate for patients who lost a few fingers in a similar way. Nowadays, we have at our disposal many reconstructive weapons that provide the opportunity to not accept defeat easily. Nevertheless, since the infection rates in injuries with farming devices are high $^{[3]}$ and given the presence of amputations that are not appropriate for micro-surgery, ${ }^{[4]}$ the number of cases that result in limb and severe functional loss is not low. In the literature, despite the fact that some manuscripts have reported that all re-implanted cases of amputations due to farming machines have failed, ${ }^{[4]}$ some reports have suggested that a number of cases could be saved with micro-surgery. ${ }^{[9]}$ Revascularization was attempted in only two of the reported 25 cases in this manuscript and these were successful. Other patients with amputation were injured in such a way that was not appropriate for re-implantation. In two cases amputated from the proximal wrist, since the amputated part of the extremity was smashed, re-implantation was not possible. The causes of upper extremity injuries due to farming machines include handling the engine belt of farming machines accidentally, ${ }^{[13]}$ or trying to unclog the wheat thresher or corn-pickers manually, which can become plugged with wheat or wet corn stalks. ${ }^{[4]}$ As a result of these injuries, lacerations, crushing, avulsion and friction burns, de-gloving, direct amputation or digital devascularization, and severe mutilations and later severe functional losses can be observed. ${ }^{[3,4,6,14]}$

Although there are a few articles in the literature about the classification of upper extremity injuries due to farming machines, since the present classifications do not cover all cases and an appropriate treatment algorithm cannot be created as a result of these classifications, new classifications are still necessary. ${ }^{[4,6,11,13]}$ Maxim et al. ${ }^{[6]}$ reported three types of severe hand in-

Table 3. Admission month and degree of trauma among patients

\begin{tabular}{|c|c|c|c|c|c|c|c|}
\hline Months & 1st degree & 2nd degree & 3rd degree & 4th degree & 5 th degree & 6th degree & Total \\
\hline April & & 1 & & & & & 1 \\
\hline May & & & & & 3 & & 3 \\
\hline June & 2 & & & 1 & & & 3 \\
\hline July & & & & 1 & 1 & & 2 \\
\hline August & 3 & 1 & 3 & & 4 & & 11 \\
\hline September & & & & 1 & 2 & 2 & 5 \\
\hline Total & 5 & 2 & 3 & 3 & 10 & 2 & 25 \\
\hline
\end{tabular}

Table 4. Admission year and degree of trauma among patients

\begin{tabular}{lccccccc}
\hline Years & 1st degree & 2nd degree & 3rd degree & 4th degree & 5th degree & 6th degree & Total \\
\hline 2007 & 1 & 1 & & 1 & & 3 \\
2008 & 2 & 1 & 3 & 2 & 6 & 7 \\
2009 & 2 & & 3 & 3 & 10 & 2 & 15 \\
Total & 5 & 2 & 3 & & 25 \\
\hline
\end{tabular}


juries due to corn-picker accidents in their study reported in 1954. Type 1 included the injuries in which the thumb was preserved but the other fingers were lost; type 2 included the injuries in which all fingers including the thumb were lost; and type 3 included the injuries in which one or more fingers were lost in the radial aspect of the hand together with the thumb. On the other hand, Gorsche and Wood ${ }^{[4]}$ used the classification of Maxim et al. in their study in 1988; however, since they had patients in types 1 and 2 groups but did not have any patients in the type 3 group, they revised type 3 to indicate hand injury in which the thumb and at least one finger were preserved but the other fingers were amputated. Both of these classifications only included multiple hand injuries and did not cover other injury types. Alternatively, Ozyurekoglu et al. ${ }^{[11]}$ classified 21 cases with injuries due to hay baler as group 1: single digit injury; group 2: viable hand with limited tissue injury or loss; group 3: viable hand with extensive tissue loss; group 4: amputation or devascularization with limited tissue injury or loss; and group 5: amputation or devascularization with extensive tissue loss. In this type of classification, there were no data about the involved tissue in the injury (bones, tendons, nerves, vessels, etc). In 2004, Terzioglu et al. ${ }^{[13]}$ suggested classifying the hand injuries due to farming machines as 1st degree: soft tissue injury; 2nd degree: degree $1+$ tendinous injury; 3rd degree: degree $2+$ bony injury; 4th degree: degree $3+$ vascular and nerve injury; and 5th degree: amputation. In our opinion, the most appropriate classification among the reported classifications on this topic seems to be the classification of Terzioglu et al. However, this classification does not cover all cases. For example, a case with only bone fracture and soft tissue injury without tendon damage cannot be classified according to this classification (Case 23 in the current study). Furthermore, a patient with a distal phalanx amputation would be evaluated in the same category as a patient with hand or arm amputations. The classification suggested in this manuscript is a modified version of the classification of Terzioglu.

The time for product collection in our region is between the second half of April and September. Momcilovic et al. ${ }^{[5]}$ reported that farm machine injuries were more commonly seen in the month of October. On the other hand, while Terzioglu et al. described that these injuries peaked in the months of July and August, ${ }^{[13]}$ Ozyurekoglu et al ${ }^{[11]}$ reported this peak in the month of June. In our study, threshing machine injuries were most commonly observed in the month of August. This may be attributed to the fact that the highest air temperature felt in this region was in the month of August. There are a number of articles in the literature about the negative effects of the hot environment on the workers. ${ }^{[15-17]}$ Working under conditions of thermal stress has associated risks and consequences. Impairment of mental function and increased fatigue have implications for workplace safety. In a retrospective evaluation of the cases, it was observed that $60 \%(15 / 25)$ of cases were admitted in the last year. This may be attributed to the more widespread use of farming machinery in agriculture. A special age group at risk for injuries due to farming machines is children. ${ }^{[12]}$ Ninety percent of agricultural injuries were reported to be seen in the childhood period. ${ }^{[18]}$ In the reported case series here, $60 \%(15 / 25)$ of the patients were aged 15 years or younger. In particular, children living on farms or children staying with their parents while they are working can be easily injured by farming machines.

It is clear that preventing hand injuries due to agricultural machines is more beneficial than developing new treatment modalities for these injuries. Grogono et al. ${ }^{[10]}$ reported that for grain auger injuries, the part of the machine that caused the accidents most commonly could be kept under a protective shield. On the other hand, Ozgenel et al. ${ }^{[19]}$ stated that informing the farming families (by physicians), providing communication via the media and government agencies, and shielding the rotating components of agricultural machines can be effective.

In conclusion, forbidding the entrance of children to areas with agricultural machines, informing children in schools (in those regions with developing agriculture) about agricultural accidents and their prevention methods, and adjusting the working hours of farming personnel, especially in the hottest months of the year, may be beneficial in preventing accidents due to farming machines.

\section{REFERENCES}

1. Solomon C. Accidental injuries in agriculture in the UK. Occup Med (Lond) 2002;52:461-6.

2. Leigh JP, McCurdy SA, Schenker MB. Costs of occupational injuries in agriculture. Public Health Rep 2001;116:235-48.

3. Melvin PM. Corn picker injuries of the hand. Arch Surg 1972;104:26-9.

4. Gorsche TS, Wood MB. Mutilating corn-picker injuries of the hand. J Hand Surg Am 1988;13:423-7.

5. Momcilović D, Prokes B, Janjić Z. Mechanical cornpicker hand injuries. Med Pregl 2005;58:479-82.

6. Maxim ES, Webster FS, Willander DA. The cornpicker hand. J Bone Joint Surg Am 1954;36:21-9.

7. Chari PS, Kharshiing W, Balakrishnan C. Wheat thresher hand injuries. Indian J Med Res 1975;63:829-32.

8. Hansen RH. Major injuries due to agricultural machinery. Ann Plast Surg 1986;17:59-64

9. Beatty ME, Zook EG, Russell RC, Kinkead LR. Grain auger injuries: the replacement of the corn picker injury? Plast Reconstr Surg 1982;69:96-102.

10. Grogono BJ. Auger injuries. Injury 1973;4:247-57.

11. Ozyürekoğlu T, Napolitano M, Kleinert JM. Hay baler inju- 
ries to the upper extremity. J Trauma 2007;63:62-9.

12. Angoules AG, Lindner T, Vrentzos G, Papakostidis C, Giannoudis PV. Prevalence and current concepts of management of farmyard injuries. Injury 2007;38:S27-34.

13. Terzioglu A, Aslan G, Ates L. Injuries to children's hands caused by the engine belts of agricultural machines: classification and treatment. Scand J Plast Reconstr Surg Hand Surg 2004;38:297-300.

14. Bruner JM. Corn picker injuries of the hand. Plast Reconstr Surg Transplant Bull 1958;21:306-14.

15. Tanaka M. Heat stress standard for hot work environments in Japan. Ind Health 2007;45:85-90.
16. Nag PK, Nag A, Ashtekar SP. Thermal limits of men in moderate to heavy work in tropical farming. Ind Health 2007;45:107-17.

17. Miller VS, Bates GP. The thermal work limit is a simple reliable heat index for the protection of workers in thermally stressful environments. Ann Occup Hyg 2007;51:553-61.

18. Hartling L, Brison RJ, Crumley ET, Klassen TP, Pickett W. A systematic review of interventions to prevent childhood farm injuries. Pediatrics 2004;114:483-96.

19. Ozgenel GY, Akin S, Ozbek S, Kahveci R, Ozcan M. Severe hand injuries in children related to farm tractors: a report of 70 cases. Ulus Travma Acil Cerrahi Derg 2008;14:299-302. 